\title{
Activity-dependent plasticity of electrical synapses: increasing evidence for its presence and functional roles in the mammalian brain
}

\author{
Julie S. Haas ${ }^{1 *}$, Corey M. Greenwald ${ }^{1}$ and Alberto E. Pereda ${ }^{2}$
}

From International Gap Junction Conference 2015

Valparaiso, Chile. 28 March - 2 April 2015

\begin{abstract}
Gap junctions mediate electrical synaptic transmission between neurons. While the actions of neurotransmitter modulators on the conductance of gap junctions have been extensively documented, increasing evidence indicates they can also be influenced by the ongoing activity of neural networks, in most cases via local interactions with nearby glutamatergic synapses. We review here early evidence for the existence of activity-dependent regulatory mechanisms as well recent examples reported in mammalian brain. The ubiquitous distribution of both neuronal connexins and the molecules involved suggest this phenomenon is widespread and represents a property of electrical transmission in general.
\end{abstract}

\section{Background}

The functions of electrical synapses have recently been of increasing interest within the neuroscience community. Electrical transmission is supported by gap junctions, structures that are formed by plaques of paired and docked connexin-formed hemichannel pores in apposed neuronal cell membranes. These channels form a physical connection between cells, allowing ionic current to flow directly between coupled neurons. Electrical synapses in most mature mammalian neuronal systems are composed of connexin36 (Cx36) [1-3] and connect, amongst many cell types, GABAergic neurons of similar biochemical subtype $[4,5]$, which are widespread. Both gap junctions between neurons and electrical transmission have been identified in a still-increasing number of systems and brain areas, reinforcing the notion that electrical synapses contribute vitally to information processing across the brain.

\footnotetext{
* Correspondence: julie.haas@lehigh.edu

${ }^{1}$ Department of Biological Sciences, Lehigh University, Bethlehem, PA 18015, USA

Full list of author information is available at the end of the article
}

Like chemical synapses, electrical synapses can vary their gain [6, 7]. Modifications of synaptic strength are thought to underlie important functional processes, including learning and memory $[8,9]$. Modification of the strength of electrical synapses was initially reported as a result of the action of neurotransmitter modulators [6, $10]$, such as dopamine [11], which also modulates chemical synapses [12] and neuronal excitability [13].

More recent evidence indicates that the strength of electrical synapses is influenced by ongoing activity in neural networks, via interactions with chemical synapses [14]. 'Activity-dependent plasticity' of electrical transmission was initially reported in fish, at auditory nerve mixed synapses on the Mauthner cells [15]. Here we review mammalian structures in which activity-dependent plasticity of electrical transmission has been demonstrated: the retina, the thalamic reticular nucleus (TRN) and the inferior olive, as well early evidence in the anterior hypothalamus. Both the widespread distribution of the involved molecules and common regulatory mechanisms suggest that plasticity is an essential and ubiquitous property of electrical transmission in the mammalian brain. 


\section{Mixed synapses on the Mauthner cells}

Mauthner cells mediate escape reflex in fish (and amphibian tadpoles) and receive auditory input from the nerve afferents that terminate as 'club endings', a synapse that combines chemical and electrical transmission [16-18]. Electrical synapses between VIIIth-nerve auditory afferents and Mauthner cells are composed of hemichannels formed by two teleost homologs of the mammalian Cx36: Cx35 at presynaptic hemiplaque sides, and Cx34.7 at postsynaptic hemiplaques, form heterotypic gap junctions [19]. This molecular asymmetry is mirrored by functional asymmetry, averaging a 4-fold differential of electrical transmission in favor of the presynaptic club ending, also enhancing the excitability of neighboring club endings onto the same Mauthner cell.

Several types of stimuli have been shown to induce plasticity of the electrical component within these synapses. Discontinuous bursts of tetanizing stimulation of the VIIIth nerve leads to long-term potentiation of the electrical component of the EPSP $[15,20,21]$ with a parallel increase in the chemical excitatory component of the EPSP. This form of plasticity depends on calcium $\left(\mathrm{Ca}^{2+}\right)$ increase, which activates a $\mathrm{Ca}^{2+} /$ calmodulindependent kinase (CaMKII) [22], and involves nearby NMDARs [23]. Brief continuous high-frequency stimulation of the VIIIth nerve also leads to potentiation, through mGluR1-dependent endocannabinoid production and release of dopamine, which in turn acts postsynaptically via activation of D1/5 receptors and cAMP-dependent protein kinase A (PKA) [24]. Thus, both forms of activitydependent potentiation of the Mauthner synapse depend on the activation of glutamate receptors localized in the same contact. In addition, activation of opioid receptors was shown to lead to long-term enhancement of electrical (and glutamatergic) transmission at Mauthner cells. Although no specific forms of neuronal activity patterns have been so far identified for this mechanism it also requires as in the case of endocannabinoids activation of dopamine D1/5 receptors and postsynaptic PKA [25], suggesting the existence of interactions between both potentiating mechanisms.

Together, these results indicate a high degree of sensitivity of Mauthner electrical synapses to neuronal activity and signaling. While the sensory stimulus that triggers an escape response is likely multimodal, and combines vestibular and lateral line information [26, 27], the plasticity of the electrical component of the synapse is likely to render the Mauthner cell more responsive to afferent stimuli both from the VIIIth nerve and, potentially, from other afferents. Enhanced electrical coupling would feed the depolarization produced by other active afferents back to neighboring inactive synapses, increase their excitability and promote cooperativity between afferents to the Mauthner cell $[28,29]$. The phenomenon of lateral excitation is also supported by the functional asymmetry of this synapse, which favors electrical transmission in the antidromic direction (from the Mauthner cell to the presynaptic afferents) [19]. While reliable depressing stimuli has yet to be identified (but see [30]), we speculate that plasticity in this synapse is an important component in online adjustments in the overall sensitivity of the Mauthner cell, and the associated escape reflex, to afferent sensory information.

\section{Retina}

The retina has provided the earliest and more numerous examples of regulation of electrical synapses by neurotransmitter modulators. Electrical synapses appear widely across the retina, which contains layered structures of cells that are conserved between fish and mammalian retinas. Variations in electrical synapse strength contribute to tuning the sensitivity of retinal circuits for transitioning between nighttime and daytime visual tasks. In the outer layer, coupling connects both functionally similar (e.g. conecone) and dissimilar (rod-cone) types of photoreceptors. Dispersion of voltage signals between cells helps to suppress voltage noise in individual cells. Moreover, the rod pathway informs the cone pathway of light levels at the upper end of its dynamic range. In bright light, rod-cone coupling is reduced and rod input is effectively eliminated from the cone pathway by a dopamine-mediated circadian mechanism [31, 32]. In goldfish, activation of dopamine receptors in the daylight, and adenosine by night, regulates PKA-mediated phosphorylation of Cx36 in mouse cone cells [33]. Modifications in coupling have also been demonstrated in the inner nuclear layer. Here, dopamine regulates coupling between horizontal cells, which express gap junctions based on the connexins Cx57 or Cx50 in mammals and several homologous connexins in fish, by modulating open probability [11, 34]. Retinal AII amacrine cells are extensively coupled with other AII amacrine cells, and with cone bipolar cells.

In addition to the action of neuromodulators, recent data indicates that mammalian retinal electrical synapses are also sensitive to activity of glutamatergic synapses. That is, AII amacrine cell synapses undergo changes in electrical coupling driven by light adaptation [35], in which glutamate spillover from bipolar cell spiking activity produces enhancement of coupling via activation of NMDA receptors, CaMKII, and phosphorylation of Cx36 [36]. Retinal electrical synapses are but one of many mechanisms that contribute to the visual adaptation processes necessary to meaningfully handle overall changes in light intensity over a billion-fold range. The retina contains many embedded microcircuits that process different specific features of the visual world in parallel. Activity-driven glutamate-dependent electrical synapse plasticity may 
tune and/or isolate these feature-selective pathways within that circuit.

\section{Inferior olive}

The olivo-cerebellar network provides the timing signals necessary for precise coordination of motor actions, and for non-motor and cognitive tasks. Within the network, neurons of the inferior olive (IO) provide the powerful excitatory climbing fiber input to Purkinje neurons. The clock of the timing signals in the cerebellum is thought to be provided by subthreshold $5-10 \mathrm{~Hz}$ oscillations produced by intrinsic mechanisms within neurons of the IO [37-39]. Electrical coupling between IO cells is thought to synchronize their sparse spikes [37, 40, 41].

IO neurons are also influenced by GABAergic input from the cerebellar nuclei in IO glomeruli, where dendrites of neighboring $\mathrm{IO}$ neurons are connected via gap junctions [42] that are thus electrotonically distant from the somatic integrator. [For this reason, coupling coefficients measured between somas in IO neurons are typically weak [40]]. Rodolfo Llinás and colleagues hypothesized that electrical coupling between IO neurons is transiently modulated by synaptic inputs that act as a shunt between the GJs and soma, which results in an apparent depression of electrical synapse strength [43]. This mechanism has been recently directly confirmed by optogenetic activation of GABAergic input from the cerebellar nuclei that caused a transient decrease in electrical coupling strength between olivary cells [44].

Another recent set of work has investigated long-term electrical synaptic plasticity coincident with glutamatergic activity in this structure. Long-term potentiation of electrical synapses between pairs of IO cells results from high-frequency stimulation or NMDA application, an effect dependent on intracellular $\mathrm{Ca}^{2+}$ and CaMKII activity [45]. Conversely, lower-frequency stimulation $(1 \mathrm{~Hz})$ of adjacent white matter leads to depression of coupling, an effect also mediated via activation of NMDA receptors [46]. The involvement of NMDA receptors in triggering both activity-dependent potentiation and depression of synaptic transmission was previously reported for chemical synapses [47]. NMDAR-dependent bi-directional plasticity of electrical transmission in the IO is likely related to differences in the induction protocols or small variations in the experimental conditions.

Coupling among IO neurons is highly variable, heterogeneity that was proposed to result from short-term activity-dependent plasticity at individual glomeruli [48]. Coupling was also reported to be asymmetrical [40], suggesting that substructures or microcircuits within IO circuits, defined by coupling, are formed and adjusted by ongoing changes in the strength of electrical synapses. Indeed, plasticity of electrical synapses has been proposed as a mechanism whereby motor learning and increased precision of timing is accomplished by gradual reduction of coupling strength in small subsets of IO neurons [49].

\section{Thalamic reticular nucleus}

The thalamic reticular nucleus (TRN) forms a dorsolateral shell around the thalamus proper. This structure primarily receives glutamatergic input from the corticothalamic and thalamocortical axons, and projects inhibitory GABAergic synapses to neurons of the thalamus $[50,51]$. Together, TRN neurons act to gate information between the cortex and the thalamus [52, 53]. This "spotlight" has been proposed to focus cortical attention on important stimuli though coordinated inhibition of distractions. Within the TRN, neurons are densely and strongly coupled [54, 55] by Cx36-based GJs [1].

Two forms of electrical synapse depression have emerged in the TRN. First, tetanic stimulation of cortical afferents to the TRN result in an glutamate-mediated long-term depression of electrical synapses [56]; activation of Group I mGluRs induces long-term depression, while activation of Group II receptors induces long-term potentiation, of electrical synapses in a competing pathway through cAMP and PKA [57].

Synchronous low-frequency bursting activity induced in coupled TRN neurons also leads to depression of the electrical synapses between them [58] via a yet-undetermined mechanism. Bursting activity in TRN neurons is a prominent component of both sleep spindle rhythms $[59,60]$ and the sharp wave discharges that characterize absence seizures $[61,62]$. Depression resulting from induced paired bursting in TRN neurons offers the most specific evidence to date that ongoing glutamate-driven physiologically patterned activity can modify electrical synapse strength.

In the TRN, depression of electrical synapses generally acts to desynchronize the spiking of active neurons. The TRN is a regulator of thalamocortical spindle rhythms [63]; plasticity of electrical synapses may be a regulatory mechanism for maintaining physiological levels of synchrony, by uncoupling neurons that are overly synchronized. Interestingly, transmission at electrical synapses in the TRN is asymmetrical [64] and, further, activity-induced depression of those asymmetrical synapses acts to increase that inequality of transmission [58], suggesting that plasticity could play a physiological role by selectively enhancing or diminishing asymmetry of transmission, and thereby the direction of information flow across the TRN. A thoughtprovoking possibility is that depression could occur between active sensory subsectors within the TRN, and results in dynamic isolation of one sensory modality within the nucleus from others. Alternatively, activity-dependent plasticity of electrical synapses may desynchronize neurons within a sensory subsector that are active in response to specific stimuli. 


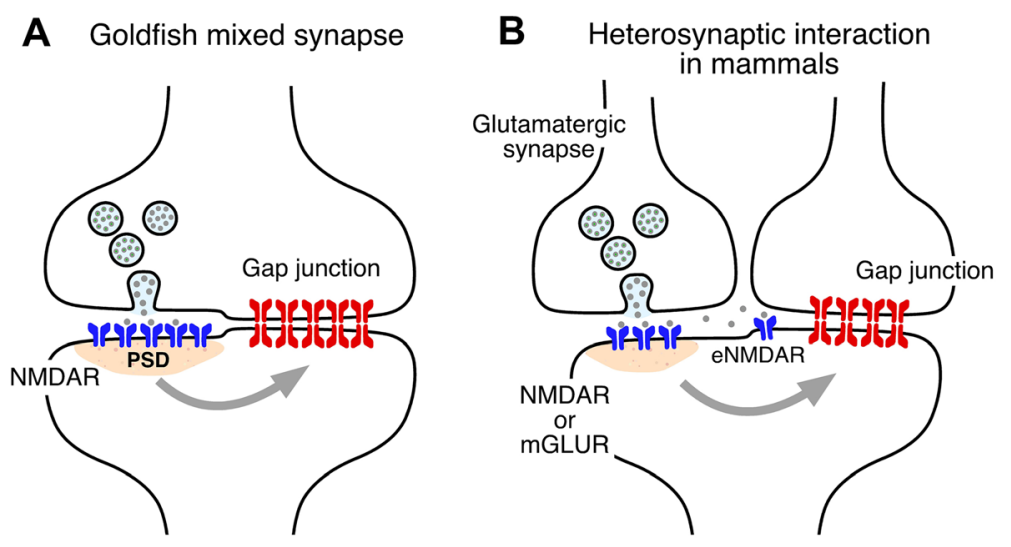

Fig. 1 Interactions between glutamatergic and electrical synapses that leads to activity-dependent potentiation of electrical transmission. a At goldfish mixed synapses the activity of co-existing glutamatergic synapses leads to activation of NMDARs which initiates changes in electrical (and chemical) transmission [the second form of activity-dependent potantiation involvimg mGluRs, endocannabinoids and dopamine is not represented]. b. At mammals, activation of mGluRs or NMDARs, including extrasynaptic NMDARs (eNMDAR), leads to changes in electrical transmission

\section{Anterior hypothalamus}

The established role of glutamatergic transmission in promoting activity-dependent plasticity of electrical transmission is consistent with earlier reports in hypothalamus. Glenn Hatton and colleagues $[65,66]$ reported that electrical stimulation of the lateral olfactory tract led to an increase in dye coupling between neurons of the supraoptic nucleus. Remarkably, this increase was observed in lactating but not virgin or male rats [66]. Although the involvement of glutamate receptors was
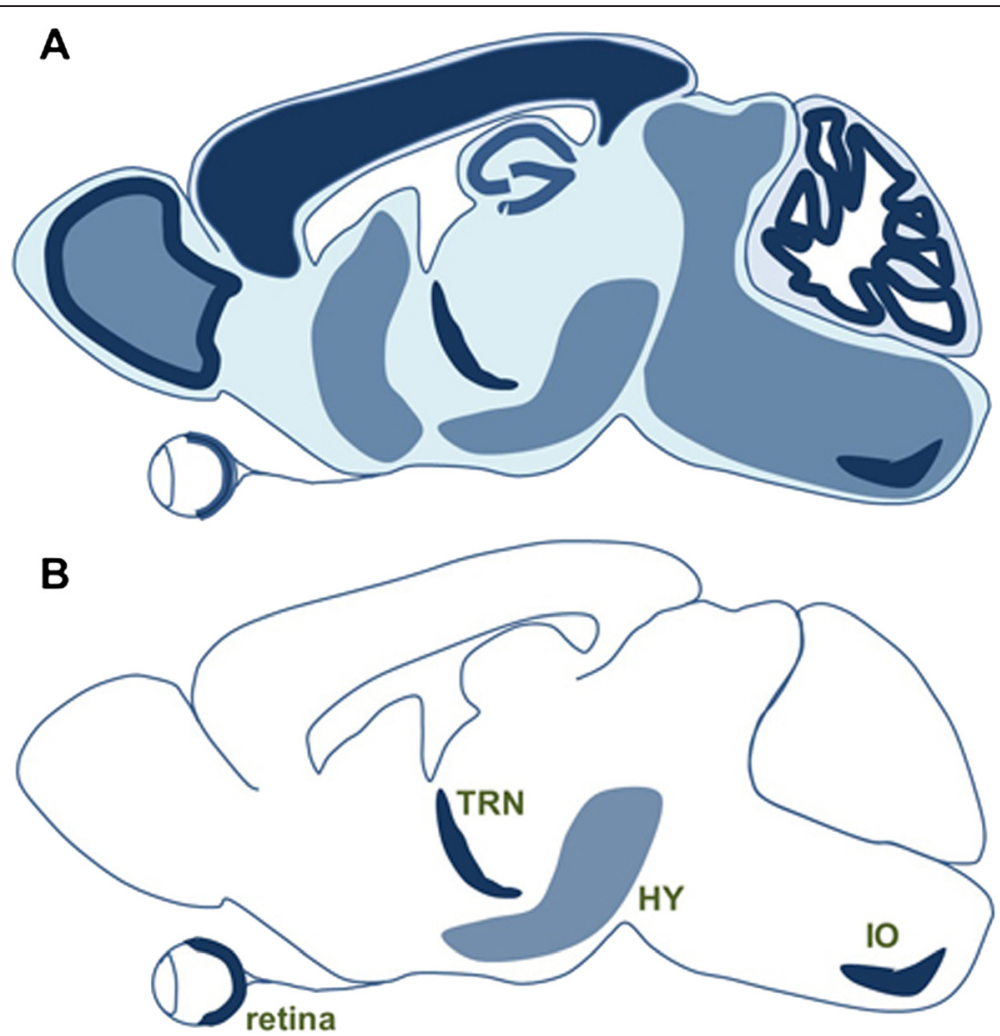

Fig. 2 Activity-dependent plasticity of electrical transmission across the mammalian brain. a Both Cx36 and GluA (a marker of glutamatergic transmission) are expressed (light filled background) broadly across the rat brain. Darker areas represent areas with higher Cx36 expression. b Activity-dependent modification of electrical transmission has been currently reported in only four areas (TRN, thalamic reticular nucleus; HY, hypothalamus; IO, inferior olive) 
not pharmacologically tested in those experiments, the lateral olfactory tract is known to carry monosynaptic projections from mitral cells in the olfactory bulb which are glutamatergic in nature $[67,68]$ suggesting the involvement of their receptors in the induction of plastic changes. In retrospect this report could be then considered the first evidence of activity-dependent increase in coupling resulting from synaptic activation in the mammalian CNS. Subsequent results in the suprachiasmatic nucleus of the hypothalamus have shown a decrease in dye coupling resulting from TTX blockade of activity [69], while application of vasoactive intestinal peptide increases spiking activity [70] and coupling coefficients [71].

From the functional point of view, these data suggest that coupling increases following strong sensory inputs associated with behavior that result in increased hormone or peptide release in response to other incoming stimuli.

\section{Conclusions}

While electrical synapses are known to be the target of the neuromodulatory transmitters, increasing evidence indicates that they are profoundly influenced by the activity of the networks in which they are embedded. This activity-dependent plasticity of electrical transmission has been shown to rely, so far, on interactions with nearby chemical synapses via activation of glutamate receptors. Originally identified in fish (Fig. 1a), this form of interaction between chemical and electrical synapses has been shown to occur in at least four different mammalian structures (Fig. 1b). The widespread distribution of $\mathrm{Cx} 36$ and glutamate transmission in the mammalian CNS (Fig. 2a) suggests this interaction might be common, while these examples (Fig. 2b) represent just the tip of the iceberg. Furthermore, similar to goldfish mixed synapses, glutamate receptor-containing postsynaptic densities have been shown to be located nearby Cx36containg gap junctions in various structures of the mammalian brain [14], extrasynaptic NMDA receptors were identified in close proximity to Cx36-containing gap junctions [45, 72], and new anatomical evidence points towards the possibility of mixed synapses in the mammalian auditory brainstem [73]. Although is not the topic of this article, interactions between glutamate receptors and electrical synapses are not restricted to the adult brain. Activation of Group II mGluRs at early developmental stages leads to an increase in Cx36 expression, whereas activation of NMDARs leads to its decrease at late developmental stages (for review see [74]).

The distinction between neuromodulator-dependent and activity-dependent plasticity is somewhat arbitrary, and both regulatory processes are likely to interact. For instance, a form of activity-dependent potentiation at goldfish mixed synapses was shown to require activation of mGluR1 receptors that, by promoting the release of endocannabinoids, led to the release of dopamine from nearby varicose terminals, which in turn triggers potentiation via a postsynaptic mechanism [24, 74].

Beyond interactions with chemical synapses, activitydependent plasticity of electrical transmission is likely to occur via other mechanisms. Interestingly, a recent report indicates that the induction of gap junction plasticity occurred in the absence of chemical synaptic stimulation and was driven by bursting cellular activity [58], suggesting that plastic changes can indeed occur in the absence of interactions with nearby glutamate receptors, and are possibly initiated by ion influx during spiking activity. Finally, could the activity of electrical synapses themselves lead to their potentiation? Although so far there are no examples of this exciting possibility, gap junction channels are part of multiprotein complexes [75] and are known to be associated to a range of signaling molecules [76] including transcription factors $[77,78]$, suggesting they might be endowed with the machinery required to induce plasticity.

\section{Competing interests}

The authors declare that they have no competing interests.

\section{Authors' contributions}

JSH, CMG and AEP wrote the manuscript. All authors read and approved the final manuscript.

\section{Acknowledgements}

JSH was supported in part as the Haddie Investigator, with a 2014 NARSAD Young Investigator Grant from the Brain \& Behavior Research Foundation, and by the Whitehall Foundation. AEP was supported by National Institutes of Health grants DC03186, DC011099, NS055726, NS085772 and NS0552827.

\section{Declarations}

Publication charges for this work was partly funded by the Brain \& Behavior Research Foundation and by the Whitehall Foundation to JSH, and partly funded by NS0552827 to AEP.

This article has been published as part of BMC Cell Biology Volume 17 Supplement 1, 2016: Proceedings of the International Gap Junction Conference 2015. The full contents of the supplement are available online at http://bmccellbiol.biomedcentral.com/articles/supplements/volume-17supplement-1.

\section{Author details}

${ }^{1}$ Department of Biological Sciences, Lehigh University, Bethlehem, PA 18015, USA. ${ }^{2}$ Dominick P. Purpura Department of Neuroscience, Albert Einstein College of Medicine, Bronx, New York, NY 10461, USA.

Published: 24 May 2016

\section{References}

1. Condorelli DF, Belluardo N, Trovato-Salinaro A, Mudo G. Expression of Cx36 in mammalian neurons. Brain Res Brain Res Rev. 2000;32(1):72-85.

2. Belluardo N, Mudo G, Trovato-Salinaro A, Le Gurun S, Charollais A, SerreBeinier V, Amato G, Haefliger JA, Meda P, Condorelli DF. Expression of connexin36 in the adult and developing rat brain. Brain Res. 2000;865(1): 121-38.

3. Rash JE, Staines WA, Yasumura T, Patel D, Furman CS, Stelmack GL, Nagy Jl. Immunogold evidence that neuronal gap junctions in adult rat brain and spinal cord contain connexin-36 but not connexin-32 or connexin-43. Proc Natl Acad Sci U S A. 2000;97(13):7573-8.

4. Bennett MV, Zukin RS. Electrical coupling and neuronal synchronization in the mammalian brain. Neuron. 2004;41(4):495-511. 
5. Connors BW, Long MA. Electrical synapses in the mammalian brain. Annu Rev Neurosci. 2004;27:393-418.

6. O'Brien J. The ever-changing electrical synapse. Curr Opin Neurobiol. 2014; 29:64-72.

7. Pereda AE, Curti S, Hoge G, Cachope R, Flores CE, Rash JE. Gap junctionmediated electrical transmission: regulatory mechanisms and plasticity. Biochim Biophys Acta. 2013;1828(1):134-46.

8. Morris RG, Moser El, Riedel G, Martin SJ, Sandin J, Day M, O'Carroll C Elements of a neurobiological theory of the hippocampus: the role of activity-dependent synaptic plasticity in memory. Philos Trans R Soc Lond B Biol Sci. 2003;358(1432):773-86

9. Hebb D. The Organization of Behavior: A Neuropsychological Theory. New York: Wiley; 1949.

10. Bloomfield SA, Volgyi B. The diverse functional roles and regulation of neuronal gap junctions in the retina. Nat Rev Neurosci. 2009;10(7):495-506.

11. Lasater EM, Dowling JE. Dopamine decreases conductance of the electrical junctions between cultured retinal horizontal cells. Proc Natl Acad Sci U S A. 1985;82(9):3025-9.

12. Tritsch NX, Sabatini BL. Dopaminergic modulation of synaptic transmission in cortex and striatum. Neuron. 2012;76(1):33-50.

13. Nicola SM, Surmeier J, Malenka RC. Dopaminergic modulation of neuronal excitability in the striatum and nucleus accumbens. Annu Rev Neurosci. 2000;23:185-215.

14. Pereda AE. Electrical synapses and their functional interactions with chemical synapses. Nat Rev Neurosci. 2014;15(4):250-63.

15. Yang XD, Korn H, Faber DS. Long-term potentiation of electrotonic coupling at mixed synapses. Nature. 1990;348(6301):542-5.

16. Furshpan EJ. "Electrical transmission" at an excitatory synapse in a vertebrate brain. Science. 1964;144(3620):878-80.

17. Lin JW, Faber DS. Synaptic transmission mediated by single club endings on the goldfish mauthner cell. I. Characteristics of electrotonic and chemical postsynaptic potentials. J Neurosci. 1988;8(4):1302-12.

18. Tuttle R, Masuko S, Nakajima Y. Freeze-fracture study of the large myelinated club ending synapse on the goldfish mauthner cell: special reference to the quantitative analysis of gap junctions. J Comp Neurol. 1986;246(2):202-11.

19. Rash JE, Curti S, Vanderpool KG, Kamasawa N, Nannapaneni S, Palacios-Prado $\mathrm{N}$, Flores CE, Yasumura T, O'Brien J, Lynn BD, et al. Molecular and functional asymmetry at a vertebrate electrical synapse. Neuron. 2013;79(5):957-69.

20. Pereda AE, Faber DS. Activity-dependent short-term enhancement of intercellular coupling. J Neurosci. 1996;16(3):983-92.

21. Smith M, Pereda AE. Chemical synaptic activity modulates nearby electrical synapses. Proc Natl Acad Sci U S A. 2003;100(8):4849-54.

22. Pereda AE, Bell TD, Chang BH, Czernik AJ, Nairn AC, Soderling TR, Faber DS. Ca2+/calmodulin-dependent kinase II mediates simultaneous enhancement of gap-junctional conductance and glutamatergic transmission. Proc Natl Acad Sci U S A. 1998;95(22):13272-7.

23. Rash JE, Pereda A, Kamasawa N, Furman CS, Yasumura T, Davidson KG, Dudek FE, Olson C, Li X, Nagy Jl. High-resolution proteomic mapping in the vertebrate central nervous system: close proximity of connexin35 to NMDA glutamate receptor clusters and co-localization of connexin 36 with immunoreactivity for zonula occludens protein-1 (ZO-1). J Neurocytol. 2004;33(1):131-51.

24. Cachope R, Mackie K, Triller A, O'Brien J, Pereda AE. Potentiation of electrical and chemical synaptic transmission mediated by endocannabinoids. Neuron. 2007;56(6):1034-47.

25. Cachope R, Pereda AE. Opioids potentiate electrical synaptic transmission at mixed synapses on the mauthner cell. J Neurophysiol. 2015;114(1):689-97. doi:10.1152/jn.00165.2015.

26. Casagrand $J \mathrm{~L}$, Guzik AL, Eaton RC. Mauthner and reticulospinal responses to the onset of acoustic pressure and acceleration stimuli. J Neurophysiol. 1999;82(3):1422-37.

27. Mirjany M, Faber DS. Characteristics of the anterior lateral line nerve input to the mauthner cell. J Exp Biol. 2011;214(Pt 20):3368-77.

28. Pereda AE, Bell TD, Faber DS. Retrograde synaptic communication via gap junctions coupling auditory afferents to the mauthner cell. J Neurosci. 1995; 15(9):5943-55

29. Curti S, Pereda AE. Voltage-dependent enhancement of electrical coupling by a subthreshold sodium current. J Neurosci. 2004;24(16):3999-4010.

30. Yang XD, Faber DS. Initial synaptic efficacy influences induction and expression of long-term changes in transmission. Proc Natl Acad Sci U S A. 1991;88(10): 4299-303.
31. Ribelayga C, Wang Y, Mangel SC. Dopamine mediates circadian clock regulation of rod and cone input to fish retinal horizontal cells. J Physiol. 2002;544(Pt 3):801-16.

32. Ribelayga C, Cao Y, Mangel SC. The circadian clock in the retina controls rod-cone coupling. Neuron. 2008;59(5):790-801.

33. Li H, Zhang Z, Blackburn MR, Wang SW, Ribelayga CP, O'Brien J. Adenosine and dopamine receptors coregulate photoreceptor coupling via gap junction phosphorylation in mouse retina. J Neurosci. 2013;33(7):3135-50.

34. McMahon DG, Knapp AG, Dowling JE. Horizontal cell gap junctions: singlechannel conductance and modulation by dopamine. Proc Natl Acad Sci U S A. 1989;86(19):7639-43.

35. Bloomfield SA, Volgyi B. Function and plasticity of homologous coupling between All amacrine cells. Vision Res. 2004;44(28):3297-306.

36. W. Kothmann, E.B. Trexler, C.M. Whitaker, W. Li, S.C. Massey, J.O. O'Brien, Nonsynaptic NMDA receptors mediate activity-dependent plasticity of gap junctional coupling in the All amacrine cell network, J. Neurosci. 32 (2012) 6747-6759.

37. Long MA, Deans MR, Paul DL, Connors BW. Rhythmicity without synchrony in the electrically uncoupled inferior olive. J Neurosci. 2002; 22(24):10898-905

38. Llinas R, Yarom Y. Oscillatory properties of guinea-pig inferior olivary neurones and their pharmacological modulation: an in vitro study. J Physiol. 1986;376:163-82

39. Chorev E, Yarom Y, Lampl I. Rhythmic episodes of subthreshold membrane potential oscillations in the rat inferior olive nuclei in vivo. J Neurosci. 2007; 27(19):5043-52.

40. Devor A, Yarom Y. Electrotonic coupling in the inferior olivary nucleus revealed by simultaneous double patch recordings. J Neurophysiol. 2002; 87(6):3048-58.

41. Mann-Metzer P, Yarom Y. Electrotonic coupling interacts with intrinsic properties to generate synchronized activity in cerebellar networks of inhibitory interneurons. J Neurosci. 1999;19(9):3298-306.

42. De Zeeuw Cl, Simpson Il, Hoogenraad CC, Galjart N, Koekkoek SK, Ruigrok TJ. Microcircuitry and function of the inferior olive. Trends Neurosci. 1998; 21(9):391-400

43. Llinas R. Eighteenth Bowditch lecture. Motor aspects of cerebellar control. Physiologist. 1974;17(1):19-46.

44. Lefler $Y$, Yarom $Y$, Uusisaari MY. Cerebellar inhibitory input to the inferior olive decreases electrical coupling and blocks subthreshold oscillations. Neuron. 2014;81(6):1389-400.

45. Turecek J, Yuen GS, Han VZ, Zeng XH, Bayer KU, Welsh JP. NMDA receptor activation strengthens weak electrical coupling in mammalian brain. Neuron. 2014;81(6):1375-88.

46. Mathy A, Clark BA, Hausser M. Synaptically induced long-term modulation of electrical coupling in the inferior olive. Neuron. 2014;81(6):1290-6.

47. Malenka RC, Nicoll RA. NMDA-receptor-dependent synaptic plasticity: multiple forms and mechanisms. Trends Neurosci. 1993:16(12):521-7.

48. Hoge GJ, Davidson KG, Yasumura T, Castillo PE, Rash JE, Pereda AE. The extent and strength of electrical coupling between inferior olivary neurons is heterogeneous. J Neurophysiol. 2011;105(3):1089-101.

49. Tokuda IT, Hoang H, Schweighofer N, Kawato M. Adaptive coupling of inferior olive neurons in cerebellar learning. Neural Netw. 2013;47:42-50.

50. Ohara PT, Lieberman AR. The thalamic reticular nucleus of the adult rat: experimental anatomical studies. J Neurocytol. 1985;14(3):365-411.

51. Pinault $D$, Deschenes M. Projection and innervation patterns of individual thalamic reticular axons in the thalamus of the adult rat: a three-dimensional, graphic, and morphometric analysis. J Comp Neurol. 1998;391(2):180-203.

52. Crick F. Function of the thalamic reticular complex: the searchlight hypothesis. Proc Natl Acad Sci U S A. 1984;81(14):4586-90.

53. McAlonan K, Cavanaugh J, Wurtz RH. Attentional modulation of thalamic reticular neurons. J Neurosci. 2006;26(16):4444-50.

54. Landisman CE, Long MA, Beierlein M, Deans MR, Paul DL, Connors BW. Electrical synapses in the thalamic reticular nucleus. J Neurosci. 2002;22(3):1002-9.

55. Long MA, Landisman CE, Connors BW. Small clusters of electrically coupled neurons generate synchronous rhythms in the thalamic reticular nucleus. Neurosci. 2004:24(2):341-9.

56. Landisman CE, Connors BW. Long-term modulation of electrical synapses in the mammalian thalamus. Science. 2005:310(5755):1809-13.

57. Wang Z, Neely R, Landisman CE. Activation of group I and group II metabotropic glutamate receptors causes LTD and LTP of electrical synapses in the Rat thalamic reticular nucleus. J Neurosci. 2015;35(19):7616-25. 
58. Haas JS, Zavala B, Landisman CE. Activity-dependent long-term depression of electrical synapses. Science. 2011;334(6054):389-93.

59. von Krosigk M, Bal T, McCormick DA. Cellular mechanisms of a synchronized oscillation in the thalamus. Science. 1993;261(5119):361-4.

60. Deschenes M, Paradis M, Roy JP, Steriade M. Electrophysiology of neurons of lateral thalamic nuclei in cat: resting properties and burst discharges. J Neurophysiol. 1984;51(6):1196-219.

61. Steriade M. Sleep, epilepsy and thalamic reticular inhibitory neurons. Trends Neurosci. 2005;28(6):317-24.

62. Inoue M, Duysens J, Vossen JM, Coenen AM. Thalamic multiple-unit activity underlying spike-wave discharges in anesthetized rats. Brain Res. 1993; 612(1-2):35-40.

63. Steriade M, Domich L, Oakson G, Deschenes $M$. The deafferented reticular thalamic nucleus generates spindle rhythmicity. J Neurophysiol. 1987;57(1): 260-73.

64. Sevetson J, Haas JS. Asymmetry and modulation of spike timing in electrically coupled neurons. J Neurophysiol. 2015;113(6):1743-51. doi:10.1152/jn.00843.2014.

65. Modney BK, Yang QZ, Hatton Gl. Activation of excitatory amino acid inputs to supraoptic neurons. II. Increased dye-coupling in maternally behaving virgin rats. Brain Res. 1990;513(2):270-3.

66. Hatton Gl, Yang QZ. Activation of excitatory amino acid inputs to supraoptic neurons. I. Induced increases in dye-coupling in lactating, but not virgin or male rats. Brain Res. 1990;513(2):264-9.

67. Blakely RD, Ory-Lavollee L, Grzanna R, Koller KJ, Coyle JT. Selective immunocytochemical staining of mitral cells in rat olfactory bulb with affinity purified antibodies against N-acetyl-aspartyl-glutamate. Brain Res. 1987:402(2):373-8.

68. Ffrench-Mullen JM, Koller K, Zaczek R, Coyle JT, Hori N, Carpenter DO. Nacetylaspartylglutamate: possible role as the neurotransmitter of the lateral olfactory tract. Proc Natl Acad Sci U S A. 1985;82(11):3897-900.

69. Colwell CS. Rhythmic coupling among cells in the suprachiasmatic nucleus. J Neurobiol. 2000;43(4):379-88.

70. Kudo T, Tahara Y, Gamble KL, McMahon DG, Block GD, Colwell CS. Vasoactive intestinal peptide produces long-lasting changes in neural activity in the suprachiasmatic nucleus. J Neurophysiol. 2013;1 10(5):1097-106.

71. Wang MH, Chen N, Wang JH. The coupling features of electrical synapses modulate neuronal synchrony in hypothalamic superachiasmatic nucleus. Brain Res. 2014;1550:9-17.

72. Kothmann WW, Trexler EB, Whitaker CM, Li W, Massey SC, O'Brien J. Nonsynaptic NMDA receptors mediate activity-dependent plasticity of gap junctional coupling in the All amacrine cell network. J Neurosci. 2012;32(20): 6747-59.

73. Rubio ME, Nagy Jl. Connexin36 expression in major centers of the auditory system in the CNS of mouse and rat: evidence for neurons forming purely electrical synapses and morphologically mixed synapses. Neuroscience. 2015;303:604-29

74. Belousov AB, Fontes JD. Neuronal gap junctions: making and breaking connections during development and injury. Trends Neurosci. 2013;36(4):227-36.

75. Herve JC, Derangeon M, Sarrouilhe D, Giepmans BN, Bourmeyster N. Gap junctional channels are parts of multiprotein complexes. Biochim Biophys Acta. 2012;1818(8):1844-65.

76. Alev C, Urschel S, Sonntag S, Zoidl G, Fort AG, Hoher T, Matsubara M, Willecke K, Spray DC, Dermietzel R. The neuronal connexin36 interacts with and is phosphorylated by CaMKII in a way similar to CaMKII interaction with glutamate receptors. Proc Natl Acad Sci U S A. 2008;105(52):20964-9.

77. Penes MC, Li X, Nagy Jl. Expression of zonula occludens-1 (ZO-1) and the transcription factor ZO-1-associated nucleic acid-binding protein (ZONAB)MsY3 in glial cells and colocalization at oligodendrocyte and astrocyte gap junctions in mouse brain. Eur J Neurosci. 2005;22(2):404-18.

78. Ciolofan C, Li XB, Olson C, Kamasawa N, Gebhardt BR, Yasumura T, Morita M, Rash JE, Nagy Jl. Association of connexin36 and zonula occludens-1 with zonula occludens-2 and the transcription factor zonula occludens-1associated nucleic acid-binding protein at neuronal gap junctions in rodent retina. Neuroscience. 2006;140(2):433-51.

\section{Submit your next manuscript to BioMed Central and we will help you at every step:}

- We accept pre-submission inquiries

- Our selector tool helps you to find the most relevant journal

- We provide round the clock customer support

- Convenient online submission

- Thorough peer review

- Inclusion in PubMed and all major indexing services

- Maximum visibility for your research

Submit your manuscript at www.biomedcentral.com/submit

) Biomed Central 